\title{
PERANCANGAN ULANG TATA LETAK FASILITAS INDUSTRI TAHU DENGAN ALGORITMA BLOCPLAN DI UD. PINTU AIR
}

\author{
R. RIZKI AMALIA ${ }^{1 *}$, LUTHFINA ARIYANI ${ }^{1}$, MUHAMMAD NOOR ${ }^{1}$ \\ IJurusan Teknologi Industri Pertanian, Politeknik Negeri Tanah Laut, Jl. A.Yani, Km.6, \\ Desa Panggung, kec. Pelaihari, kab. Tanah Laut, Kalimantan Selatan 70815. Indonesia. \\ *Email: ra.amalia.rizki@gmail.com
}

\begin{abstract}
UD Pintu Air is one of the business industry that engaged in the tofu production. Currently the layout of production facilities at UD Pintu Air has constraint related to the arrangement of material movement. This study aims to redesign the layout of the tofu industry in order to minimize material handling. The approach used in the redesign process at UD. Pintu Air is Blocplan Algorithm. Moreover, the material handling efficiency is used as parameter to determine the success of the redesign process. Based on the Blocplan Algorithm, it can be obtained that the rectalinier total distance is 48,25 meter, while the existing layout has 55 meter rectalinier total distance. Therefore, the proposed layout using Blocplan Algorithm and distance calculation using rectalinier formula can be considered minimize the facility distance of 6.75 meter.
\end{abstract}

Keywords: Facilty Layout, Material Handling, Blocplan Algorithm, Rectalinier Distance

\begin{abstract}
ABSTRAK
UD. Pintu Air merupakan salah satu industri yang bergerak di bidang produksi tahu. Saat ini tata letak fasilitas produksi di UD. Pintu Air memiliki kendala terkait dengan pengaturan perpindahan material. Penelitian ini bertujuan untuk merancang ulang tata letak industri tahu untuk meminimalkan penanganan perpindahan material. Pendekatan yang digunakan dalam proses perancangan ulang tata letak fasilitas di UD. Pintu Air adalah dengan menggunakan metode ARC (Activity Relationship Chart) dan Algoritma BLOCPLAN. Hasil yang diperoleh yaitu jarak total rectalinier dari seluruh departemen adalah 48,25 meter, sedangkan tata letak yang saat ini diterapkan di UD. Pintu Air memiliki jarak total rectalinier dari seluruh departemen sebesar 55 meter. Oleh karena itu, perancangan tata letak yang diusulkan telah meminimalkan jarak perpindahan material sebesar 6,75 meter.
\end{abstract}

Kata Kunci: Tata Letak Fasilitas, Perpindahan material, ARC (Activity Relationship Chart), Algoritma BLOCPLAN, Jarak Rectalinier

\section{PENDAHULUAN}

Tata letak pabrik merupakan perencanaan dan pengaturan letak mesin, peralatan, aliran bahan dan orang-orang yang bekerja pada masing-masing stasiun kerja. Jika disusun secara baik, maka operasi kerja menjadi lebih efektif dan 
efisien (Wignjosoebroto, 2009). Pada dasarnya tujuan utama perancangan tata letak adalah optimasi pengaturan fasilitas-fasilitas operasi sehingga nilai yang diciptakan oleh sistem produksi akan maksimal (Purnomo, 2004).

Tata letak yang efektif dan efisien diindikasikan dengan tidak adanya aliran balik (backtracking), total perpindahan bahan yang kecil dan tidak terjadinya antrian berlebih (bottleneck) pada suatu proses. Tata letak yang efektif dan efisien dapat memberikan kontribusi untuk mengurangi waktu siklus produksi, waktu menganggur, bottleneck atau waktu penanganan material dan dapat meningkatkan output produksi (Vaidya et al., 2013).

Permasalahan yang berhubungan dengan tata letak fasilitas sering terjadi di pabrik-pabrik seperti pada pabrik pembuatan tahu di UD. Pintu Air Pelaihari. Adapun permasalahan yang terdapat pada pabrik ini adalah panjangnya jarak perpindahan material dari departemen satu ke departemen yang berkaitan, sehingga perlu dilakukan perancangan ulang fasilitas produksi yang ada di pabrik UD. Pintu Air. Oleh karena itu perlu adanya penataan ulang tata letak fasilitas untuk meminimalkan jarak perpindahan material dengan menggunakan metode Algoritma BLOCPLAN.

Menurut Siregar (2013), algoritma BLOCPLAN (Block Layout Overview with Layout Planning) merupakan algoritma heuristik yang menggunakan data kuantitatif maupun data kualitatif. Perancangan dilakukan dengan menggunakan algoritma BLOCPLAN membutuhkan peta keterkaitan hubungan aktivitas atau ARC (Activity Relationship Chart. Perancangan tata letak yang dilakukan akan menghasilkan beberapa alternatif tata letak departemen yang masing-masing mempunyai layout score, selanjutnya dipilih rancangan tata letak fasilitas yang memiliki nilai total rectilinear yang paling optimal.

Berdasarkan Adityo dkk. (2015), perancangan tata letak fasilitas produksi dengan menggunakan algoritma BLOCPLAN dapat meminimasi total jarak/ momen perpindahan material seperti pada tata letak fasilitas PT Dwi Indah Plant Indah Gunung Putri yang bergerak di divisi kertas dan plastik. Hasil yang diperoleh yaitu terjadi pengurangan momen perpindahan material dari 6224,26 meter/ hari menjadi 2739,1 meter/ hari. 


\section{METODE PENELITIAN}

\section{Teknik Pengumpulan Data}

Pengumpulan data pada penelitian ini dilakukan dengan melakukan pengamatan dan pengukuran secara langsung pada lantai produksi pada sebuah perusahaan pembuatan tahu di UD. Pintu Air. Pengukuran dan pengamatan dilakukan dengan bantuan alat ukur satuan meter, alat tulis dan dari pembimbing lapangan. Adapun data primer yang dikumpulkan secara pengukuran langsung adalah data ukuran departemen produksi, block layout lantai produksi awal, dan urutan proses produks.

Selain pengukuran langsung, data juga dapat diperoleh dari data yang dikumpulkan bersumber pada buku pedoman yang disusun oleh para ahli yang berhubungan dengan masalah yang dianalisis atau pengumpulan data-data dengan mempelajari buku-buku yang behubungan dengan tema penelitian. Mempelajari pedoman perusahaan tentang proses pengolahan tahu, jurnal tata letak fasilitas produksi industri, dan jurnal metode Algoritma BLOCPLAN.

\section{Metode Pengolahan Data}

Pengolahan data pertama dilakukan penggambaran block layout awal lantai produksi yang sesuai dengan pengukuran luas lantai pengolahan tahu berdasarkan pengukuran langsung di lokasi. Penentuan titik koordinat stasiun kerja layout awal sebelum dilakukan pengukuran jarak rectalinier yang harus dilakukan adalah menentukan titik koordinat tiap stasiun kerja. Kemudian dilakukan pembentukan Activity Relationship Chart. ARC dibuat berdasarkan pertimbangan frekuensi aliran perpindahan material antar tiap departemen. Hubungan kedekatan antar fasilitas merupakan data kualitatif yang diperlukan sebagai input bagi Software BLOCPLAN 90, dan yang terakhir pengolahan data menggunakan Software BLOCPLAN 90. 


\section{HASIL DAN PEMBAHASAN}

\section{Layout awal}

Penggambaran pada layout dilakukan dengan meninjau dari tata letak pabrik yang ada saat ini. Layout awal UD. Pintu Air dapat dilihat pada Gambar 1.

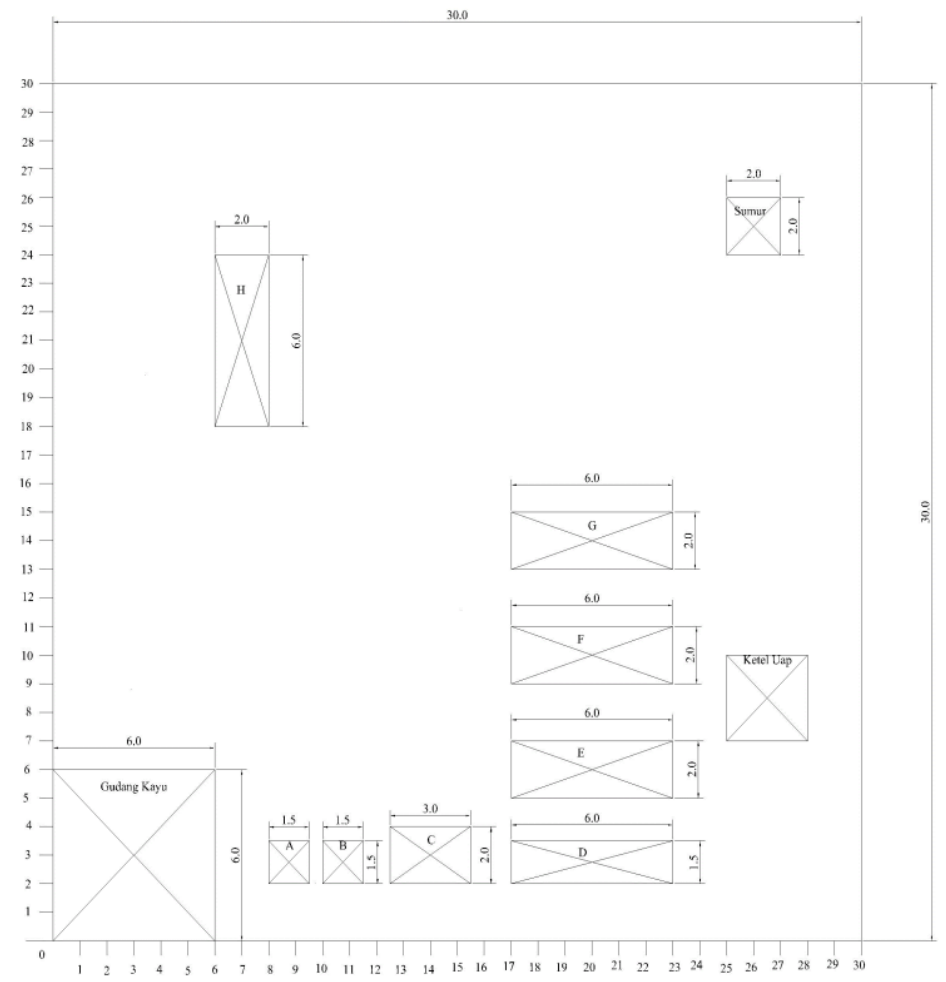

Gambar 1 Tata Letak fasilitas pabrik di UD. Pintu awal

Penggambaran lantai produksi dalam bentuk block layout dilakukan dengan meninjau dari tata letak pabrik yang ada pada saat ini. Beberapa departemen dalam proses pemindahan material terletak pada jarak yang cukup jauh dibandingkan dengan proses pemindahan material yang lain (Tabel 3) sehingga menyebabkan total jarak pemindahan bahan masih tinggi. Seperti pada proses pemindahan bahan dari departemen penggilingan ke departemen pemasakan berjarak $6 \mathrm{~m}$ dan departemen pemotongan ke departemen produk tahu berjarak $30 \mathrm{~m}$ sehingga total jarak seluruh pemindahan bahan $55 \mathrm{~m}$. 
Pengukuran luas lantai pengolahan tahu di UD. Pintu Air

Data luas lantai stasiun kerja pada UD. Pintu Air dapat dilihat pada Tabel 1.

Tabel 1. Luas lantai stasiun kerja

\begin{tabular}{clccc}
\hline No & Stasiun Kerja & Panjang $(\mathbf{m})$ & Lebar $(\mathbf{m})$ & Luas $\left(\mathbf{m}^{2}\right)$ \\
\hline 1 & Bahan baku & 1,5 & 1,5 & 2,25 \\
2 & Perendaman & 1,5 & 1,5 & 2,25 \\
3 & Penggilingan & 3 & 2 & 6 \\
4 & Pemasakan & 6 & 1,5 & 9 \\
5 & Penyaringan & 6 & 2 & 12 \\
6 & Pengendapan & 6 & 2 & 12 \\
7 & Pemotongan & 6 & 2 & 12 \\
8 & Produk tahu & 2 & 6 & 12 \\
\hline
\end{tabular}

Berdasarkan panjang dan lebar yang dihasilkan dari hasil pengukuran langsung di UD. Pintu Air diperoleh luas masing-masing stasiun kerja.

\section{Penentuan titik koordinat stasiun kerja layout awal}

Pengukuran jarak rectalinier yang harus dilakukan adalah menentukan titik koordinat tiap stasiun kerja. Tabel 2 menunjukkan Titik Koordinat Stasiun Kerja.

Tabel 2. Titik Koordinat Stasiun Kerja

\begin{tabular}{clcc}
\hline Kode & \multicolumn{1}{c}{ Stasiun Kerja } & Koordinat X & Koordinat Y \\
\hline A & Bahan baku & 8,75 & 2,75 \\
B & Perendaman & 10,75 & 2,75 \\
C & Penggilingan & 14 & 3 \\
D & Pemasakan & 20 & 2,75 \\
E & Penyaringan & 20 & 6 \\
F & Pengendapan & 20 & 10 \\
G & Pemotongan & 20 & 4 \\
H & Produk tahu & 7 & 21
\end{tabular}

Material handling dapat didefinisikan secara luas sebagai semua penanganan material dalam lingkungan manufaktur Meyers \& Stephens, (2013). Melakukan perhitungan jarak material handling antar departemen layout awal yang berkaitan, menggunakan rumus rectalinier yaitu:

$\mathrm{d}_{\mathrm{ij}}=\left|\mathrm{x}_{\mathrm{i}}-\mathrm{x}_{\mathrm{j}}\right|+\left|\mathrm{y}_{\mathrm{i}}-\mathrm{y}_{\mathrm{j}}\right|$

$\mathrm{x}_{\mathrm{ij}}=$ koordinat $\mathrm{x}$ pada pusat fasilitas $\mathrm{i}$

$\mathrm{y}_{\mathrm{ij}}=$ koordinat y pada pusat fasilitas $\mathrm{i}$ 
$\mathrm{d}_{\mathrm{ij}}=$ jarak antara pusat fasilitas $\mathrm{i}$ dan $\mathrm{j}$

Sebagai contoh perhitungan, terdapat koordinat stasiun kerja dari bahan baku $(8.75 ; 2.75)$ koordinat stasiun kerja ke perendaman $(10.75 ; 2.75)$ dapat dihitung dengan menggunakan rumus (1), sehingga jarak antara stasiun kerja bahan baku dengan stasiun kerja perendaman adalah $2.0 \mathrm{~m}$. Hasil perhitungan selengkapnya untuk seluruh stasiun kerja dapat dilihat pada Tabel 3 berikut.

Tabel 3 Perhitungan jarak material handling

\begin{tabular}{cllc}
\hline No & \multicolumn{1}{c}{ Stasiun Kerja Dari } & \multicolumn{1}{c}{ Stasiun Kerja Ke } & Jarak (m) \\
\hline 1 & Bahan Baku (A) & Perendaman (B) & 2 \\
2 & Perendaman (B) & Penggilingan (C) & 3,5 \\
3 & Penggilingan (C) & Pemasakan (D) & 6,25 \\
4 & Pemasakan (D) & Penyaringan (E) & 3,25 \\
5 & Penyaringan (E) & Pengendapan (F) & 4 \\
6 & Pengendapan (F) & Pemotongan (G) & 6 \\
7 & Pemotongan (G) & Produk Tahu (H) & 30 \\
\hline & & Jumlah & 55 \\
\hline
\end{tabular}

\section{Activity Relationship Chart (ARC)}

Tahapan selanjutnya dalam penelitian ini adalah melakukan analisis kedekatan antar departemen melalui pembuatan ARC. Hasil dari ARC dapat dilihat pada Gambar 2 berikut.

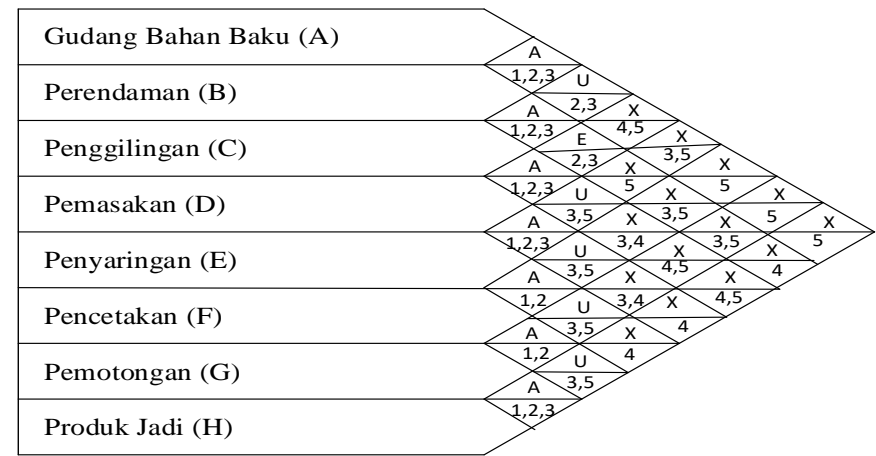

Gambar 2. Activity Relationship Chart (ARC)

Data hasil pengolahan metode Activity Relationship Chart selanjutnya diolah dalam Software BLOCPLAN (Dewi, 2008).

Pada UD. Pintu Air departemen-departemen yang mutlak untuk didekatkan yaitu departemen gudang bahan baku dengan perendaman, departemen perendaman dengan penggilingan, departemen penggilingan dengan pemasakan, departemen 
pemasakan dengan penyaringan, departemen penyaringan dengan pencetakan, departemen pencetakan dengan pemotongan, departemen pemotongan dengan tempat produk jadi. Departemen yang sangat penting didekatkan yaitu perendaman dengan pemasakan. Sedangkan departemen yang tidak penting untuk didekatkan yaitu gudang bahan baku dengan penggilingan, penggilingan dengan penyaringan, pemaskan dengan pencetakan, dan pencetakan dengan produk jadi. Selain pasangan departemen yang telah disebutkan memiliki derajat hubungan yang tidak boleh untuk didekatkan.

Perancangan tata letak fasilitas pabrik perlu mempertimbangkan hubungan keterkaitan antar fasilitas dengan alasan aliran proses produksi, aliran material, kualitas produk serta keselamatan dan kenyamanan pekerja. Bertujuan untuk meminimalkan aliran bolak-balik proses produksi yang dapat menghambat atau memperlama proses produksi (Faishol, 2013). Selain itu, penempatan departemen pada UD Pintu Air lebih tertata rapi sesuai urutan proses dan tingkat kepentingan sehingga tercipta usaha produksi yang lebih efektif dan efisien.

\section{Hasil Iterasi dengan Algoritma BLOCPLAN}

Berdasarkan tahapan proses program BLOCPLAN akan dihasilkan output dari program BLOCPLAN memuat 8 alternatif layout, untuk 8 alternatif area layout produksi pabrik seperti pada Tabel 4.

Dalam penyelesaian menggunakan metode Blocpan hanya mampu menempatkan 1 sampai 3 baris saja, dari hasil yang diperoleh software BLOCPLAN 90 terdapat batasan perpindahan stasiun kerja berdasarkan ukuran panjang dan lebar dari stasiun kerja, dari hasil pengukuran di UD. Pintu Air dapat disesuaikan dengan hasil Sofware BLOCPLAN 90. Pada Software BLOCPLAN 90 dapat digunakan untuk menganaliasa Single-Story layout dan Multistory layout. Software BLOCPLAN 90 dapat menganalisa maksimum 18 fasilitas departemen dalam satu tata letak Tompksin (1996). 
Tabel 4. Hasil Iterasi Algoritma BLOCPLAN

\begin{tabular}{ccccc}
\hline Layout & Adj.Score & \multicolumn{2}{c}{ Rel-distance score } & Produk momen \\
\hline 1 & $0.00-3$ & $0.92-2$ & $1045-1$ & $0-1$ \\
2 & $0.14-1$ & $0.74-4$ & $-890-5$ & $0-1$ \\
3 & $0.00-3$ & $0.73-5$ & $-958-3$ & $0-1$ \\
4 & $0.14-1$ & $0.93-1$ & $-1042-2$ & $0-1$ \\
5 & $-0.14-6$ & $0.61-7$ & $-778-7$ & $0-1$ \\
6 & $-0.14-6$ & $0.78-3$ & $-941-4$ & $0-1$ \\
7 & $0,00-3$ & $0.64-6$ & $-775-8$ & $0-1$ \\
8 & $-0,29-8$ & $0.57-8$ & $-818-6$ & $0-1$ \\
\hline
\end{tabular}

Dalam penelitian ini dipilih satu layout usulan dengan hasil tertinggi beserta koordinatnya yaitu dipilih layout nomor 4 dengan nilai $R$-score 0,93 . Pada gambar tata letak usulan terpilih merupakan hasil dari usulan tata letak yang mempunyai nilai tertinggi $(0<\mathrm{R}$-score $=$ maks $\{$ skor tiap alternafif tata letak $\}<1)$ sebagai tata letak terbaik, gambar tata letak usulan hasil dari program BLOCPLAN yang terpilih dengan nilai $R$-score 0,93 dapat dilihat pada tabel dibawah ini.

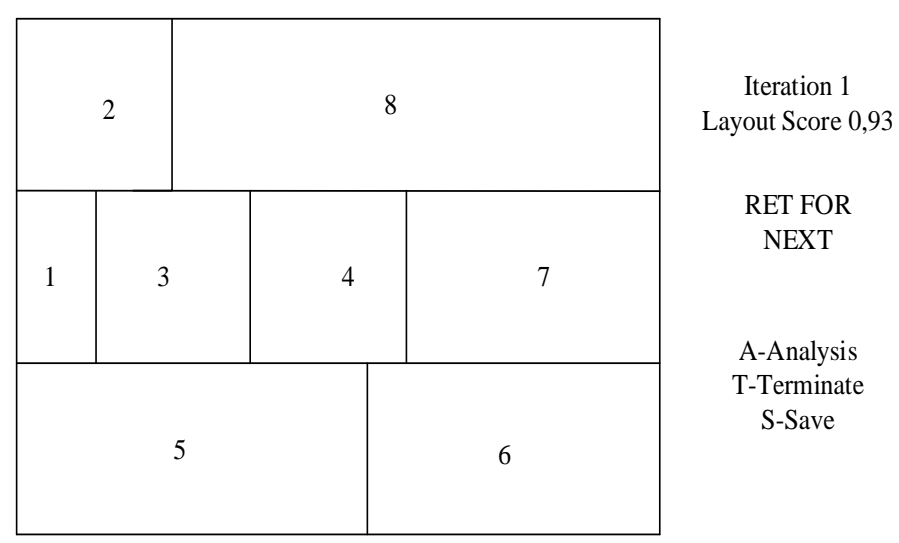

Gambar 3. Activity Template Block Diagram Pengolahan Tahu Layout Usulan

Wignjosoebroto, (2003) mengemukakan bahwa tata letak fasilitas merupakan tata cara pengaturan fasilitas-fasilitas pabrik guna menunjang kelancaran proses produksi. Dari gambar diatas Activity Template Block Diagram Pengolahan Tahu Layout Usulan yang menampilkan dari 8 kali iterasi yang menghasilkan block layout terbaik dengan layout score 0.93 . 
Pengukuran luas lantai proses pengolahan tahu layout usulan

Didalam area proses pengolahan tahu di UD. Pintu Air, luas lantai layout usulan proses pengolahan tahu berdasarkan penyesuaian yang dihasilkan dari aplikasi BLOCPLAN.

Tabel 5. Luas Lantai Pengolahan Tahu Layout Usulan

\begin{tabular}{clccc}
\hline No & Stasiun Kerja & Panjang $(\mathbf{m})$ & Lebar $(\mathbf{m})$ & Luas $\left(\mathbf{m}^{2}\right)$ \\
\hline 1 & Bahan baku & 1,5 & 1,5 & 2,25 \\
2 & Perendaman & 1,5 & 1,5 & 2,25 \\
3 & Penggilingan & 3 & 2 & 6 \\
4 & Pemasakan & 6 & 1,5 & 9 \\
5 & Penyaringan & 6 & 2 & 12 \\
6 & Pengendapan & 6 & 2 & 12 \\
7 & Pemotongan & 6 & 2 & 12 \\
8 & Produk tahu & 2 & 6 & 12 \\
\hline
\end{tabular}

Dari pengolahan layout usulan menggunakan Algoritma BLOCPLAN berdasarkan panjang dan lebar sesuai dengan layout awal yang ada di UD. Pintu Air.

\section{Penentuan nilai koordinat dan titik koordinat layout usulan}

Tata letak yang didapatkan dari hasil penyesuain didapatkan titik koordinat baru bagi departemen yang dipindahkan. Titik koordinat disetiap departemen pada layout usulan dapat dilihat pada table dibawah ini.

Tabel 6. Nilai Koordinat Layout Usulan

\begin{tabular}{clcc}
\hline No & \multicolumn{1}{c}{ Stasiun Kerja } & Koordinat X & Koordinat Y \\
\hline 1 & Bahan baku & 9,75 & 8 \\
2 & Perendaman & 9,75 & 12,75 \\
3 & Penggilingan & 13,5 & 8 \\
4 & Pemasakan & 17,25 & 8 \\
5 & Penyaringan & 12 & 3 \\
6 & Pengendapan & 19 & 3 \\
7 & Pemotongan & 21 & 8 \\
8 & Produk tahu & 19 & 13 \\
\hline
\end{tabular}


Dalam area proses pengolahan tahu di UD. Pintu Air, luas lantai proses pengolahan tahu yang ada berdasarkan layout usulan yang diperoleh dari penyesuaian algoritma BLOCPLAN 90 dapat dilihat pada gambar dibawah ini.

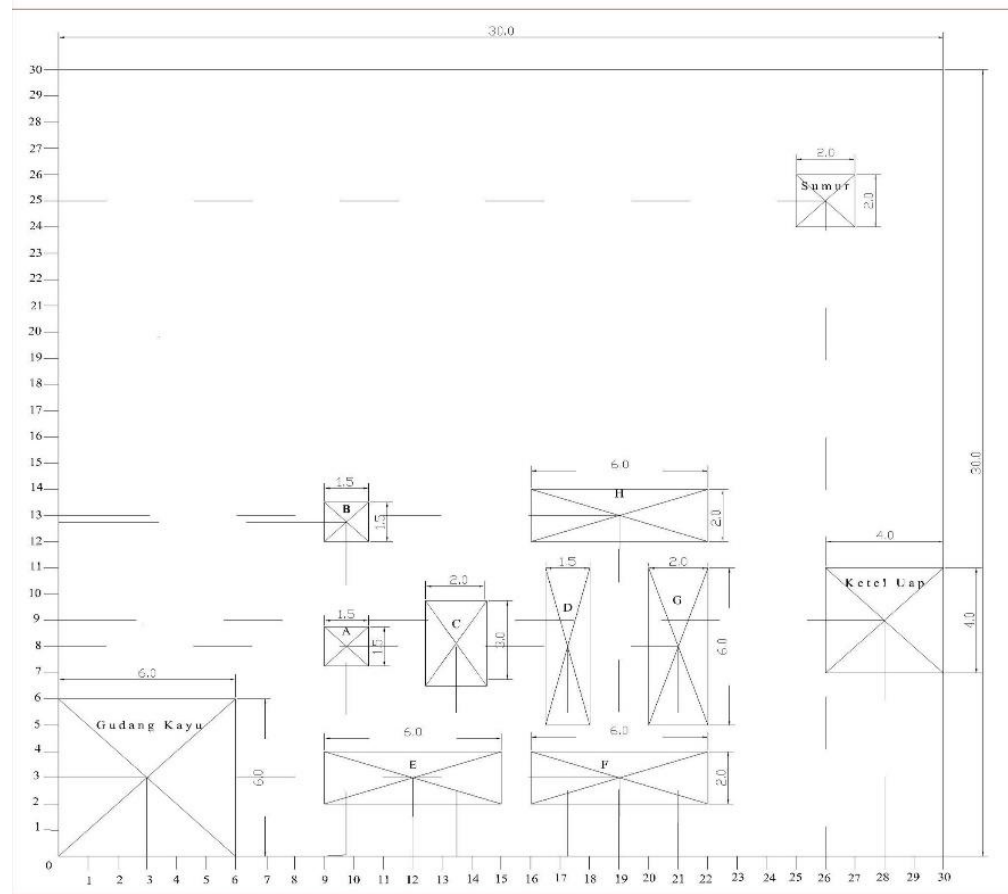

Gambar 4. layout terbaik hasil BLOCPLAN

\section{Perhitungan jarak material handling layout usulan}

Perhitungan jarak material handling ini menggunakan rumus jarak rectilinier yang diukur mengikuti jalur tegak lurus. Hasil perhitungan jarak antar stasiun kerja secara keseluruhan untuk tata letak layout usulan dapat dilihat pada tabel dibawah ini.

\section{Tabel 7. Jarak Material Handling Layout Usulan}

\begin{tabular}{cllc}
\hline No & \multicolumn{1}{c}{ Stasiun Kerja Dari } & \multicolumn{1}{c}{ Stasiun Kerja Ke } & Jarak (m) \\
\hline 1 & Bahan Baku (A) & Perendaman (B) & 4,75 \\
2 & Perendaman (B) & Penggilingan (C) & 8,5 \\
3 & Penggilingan (C) & Pemasakan (D) & 3,75 \\
4 & Pemasakan (D) & Penyaringan (E) & 10,25 \\
5 & Penyaringan (E) & Pengendapan (F) & 7 \\
6 & Pengendapan (F) & Pemotongan (G) & 7 \\
7 & Pemotongan (G) & Produk Tahu (H) & 7 \\
\hline & & Jumlah & 48,25
\end{tabular}


Jumlah perhitungan total jarak material handling antar stasiun kerja secara keseluruhan untuk tata letak layout usulan dengan menggunakan rumus rectalinier 48,25 m. Dari perbandingan yang telah dilakukan dari perhitungan jarak material handling layout awal maka dapat meminimalisasi total jarak pemindahan bahan sebesar $6,75 \mathrm{~m}$.

\section{KESIMPULAN}

Berdasarkan hasil dari pengolahan data dan analisis pembahasan mengenai perancangan ulang tata letak fasilitas yang ada pada lantai pengolahan tahu UD. Pintu Air, maka diperoleh kesimpulan yaitu dengan melakukan pendekatan fasilitas stasiun kerja pada pengolahan tahu maka akan memperpendek jarak material handling yaitu dari stasiun kerja yang satu dengan stasiun kerja yang berkaitan. Tata letak fasilitas UD. Pintu Air total jarak dengan perhitungan rectalinier total awal 55.0 meter. Sedangkan pada algoritma BLOCPLAN diperoleh 8 kali iterasi dengan iterasi yang memberikan nilai $r$-score terbesar adalah iterasi ke 4 dengan nilai 0,93, maka hasil yang diperoleh dengan rumus rectalinier total dari jarak antar stasiun kerja menjadi 48.25 meter. Dengan adanya pengurangan jarak antar stasiun kerja maka meminimumkan jarak material handling hingga 6.75 meter .

\section{UCAPAN TERIMAKASIH}

Terimakasih yang tinggi disampaikan kepada Program Studi Teknologi Industri Pertanian Politeknik Negeri Tanah Laut atas dukungan teknis maupun non teknis yang telah diberikan demi kelancaran penelitian yang telah dilaksanakan. 


\section{DAFTAR PUSTAKA}

Aditya, P., Iqbal, M., Devi, P. 2015. Perancangan Tata Letak Fasilitas Produksi pada PT Dwi Indah Plant Gunung Putri Dengan Menggunakan Algoritma BLOCPLAN. E-Proceeding of Engineering, Vol. 2, No. 1: 921.

Dewi, Andini I, Choirin, Mochamad, Efranto dan Remba Y., 2008. Perancangan Ulang Tata Letak Fasilitas Berdasarkan Hasil Simulasi Proses Produksi Rokok. Jurnal Program Studi Teknik Industri Universitas Brawijaya. Malang.

Faishol, M., Hastuti, S. dan Ulya, M. 2013. Perancangan Ulang Tata Letak Fasilitas Pabrik Tahu Srikandi Junok Bangkalan. Agrointek, Vol. 7, No. 2.

Meyers, F.E. dan Stephens, M.P., (2013), Manufacturing Facilities Design and Material Handling, Prentice Hall Inc., New Jersey.

Siregar, R.M., Sukatendel, D., dan Ukurta Tarigan.( 2013). Perancangan Ulang Tata letak Fasilitas Produksi dengan Menerapkan Algoritma Blocplan dan Algoritma CORELAP Pada PT. XYZ. Jurnal Teknik Industri FT USU. 1(1): $35-44$.

Tompkins dan J.A White, Facilities Planning 2nd ed. John Wiley and Sons, Canada, 1996.

Wignyosoebroto, S. 2003. Tata Letak Pabrik dan Pemindahan Bahan, Gunawidya.

Vaidya, R. D., Shende, P. N., N. A. Ansari and S.M. Sorte. (2013). Analysis Plant Layout for Effective Production. International Journal of Engineering and Advanced Technology (IJEAT). 2(3): 500-504. 